\title{
OPEN Kualitas Biobriket Ampas Tebu Hasil Pirolisis Sebagai Sumber Energi Alternatif
}

\author{
Alfin Ramadhan $^{\mathrm{a}^{*}}$, Anelki Amri Ghazali $^{\mathrm{a}}$, Mariyamah $^{\mathrm{a}}$
}

Abstract. At present, Indonesia needs a large energy source and the majority of energy use in Indonesia uses fossil fuels, namely fuel oil (BBM), coal, and gas. The use of fossil fuels, besides damaging the environment, is also non-renewable (nonrenewable) and unsustainable. Therefore, to anticipate environmental pollution we need another energy source that can be used by the community. In this case, biobriquette from sugarcane bagasse can be the solution because it is easy to obtain, cheap, and environmentally friendly. This study conducted 3 tests, namely: water content, heating value, and the rate of combustion where the water content testing uses a spectrameter. The samples in this study were biobriquettes with $20 \mathrm{~g}$ and $40 \mathrm{~g}$ starch adhesives, which produced the best biobriquette quality with fewer adhesives, is at AT 1 mass of $10 \mathrm{gr}$ with an adhesive composition of $20 \mathrm{gr}$ with a moisture content of $6.4 \%$, a calorific value of $5171.8048 \mathrm{cal} / \mathrm{g}$, and a combustion rate of $0.023244681 \mathrm{gr} / \mathrm{sec}$. Whereas the comparison of the quality of briquettes at AT 2 mass $13 \mathrm{gr}$ with $40 \mathrm{gr}$ adhesive composition with a moisture content of $9.8 \%$, a calorific value of 3657.352 cal / g, and a combustion rate of $0.01369863 \mathrm{gr} / \mathrm{sec}$.

Keywords : benzamide, cancer, docking, inhibitor,VEGRF2

${ }^{a}$ Department of Chemistry, Faculty of Science and Technology, Islamic State University of Raden Fatah Palembang, Palembang 30126, Indonesia .

Correspondence and requests for materials should be addressed to Ramadhan, A.

(email : alfinr401@gmail.com) 


\section{Pendahuluan}

Pada saat ini, Indonesia sedang berkembang menjadi sebuah negara industri. sebagai suatu negara industri, tentunya Indonesia membutuhkan sumber energi yang besar dan saat ini sebagian besar energi yang digunakan di Indonesia berasal dari bahan bakar fosil, yaitu bahan bakar minyak, batubara, dan gas.

Kerugian penggunaan bahan bakar fosil ini selain merusak lingkungan, juga tidak terbarukan (nonrenewable) dan tidak berkelanjutan (unsustainable) [1].

Selain itu juga, kebutuhan energi dari masyarakat di Indonesia terus meningkat setiap tahunnya dan bila tidak diantisipasi sejak sekarang tentunya akan menjadi masalah di masa yang akan datang karena energi mempunyai peranan yang sangat penting dalam berbagai kegiatan ekonomi dan kehidupan masyarakat. Oleh karena itu, untuk mengantisipasi kenaikan harga Bahan Bakar Minyak atau BBM dan gas, sehingga diperlukan sumber energi lain yang dapat digunakan untuk menggantikan peran BBM dan gas di masyarakat.

Energi biomassa dapat menjadi alternatif untuk mengatasi kelangkaan sumber energi bahan bakar minyak dan gas bumi. Salah satu jenis bahan bakar yang berasal dari biomassa adalah biobriket. Manfaat dari biobriket yakni, membantu mengatasi permasalahan dalam pengolahan sampah khususnya sampah organik, yakni mengurangi jumlah timbunan sampah, lalu sebagai alternatif bahan bakar energi terbarukan yang ekonomis. Sehingga dapat meningkatkan pendapatan masyarakat bila pembuatan biobriket ini dikelola dengan baik [2].

Biobriket dapat menggantikan penggunaan kayu bakar yang mulai meningkat konsumsinya dan menggantikan sebagian dari kegunaan minyak tanah. Biobriket merupakan sisa-sisa pengolahan lahan pertanian atau kehutanan yang masih memiliki nilai kalori dalam jumlah cukup yang masih mampu diolah menjadi briket yang dapat dimanfaatkan sebagai bahan bakar. Bahan bakar organik yang dapat diolah salah satunya adalah ampas tebu yang cukup mendapat perhatian sebagai bahan bakar alternatif dalam rumah tangga dan industri kecil [3].

Pembuatan biobriket dengan penggunaan bahan perekat akan lebih baik hasil- nya jika dibandingkan tanpa menggunakan bahan perekat. Disamping meningkatkan nilai bakar dari bioarang, kekuatan briket arang dari tekanan luar juga lebih baik (tidak mudah pecah). Perekat adalah suatu zat atau bahan yang memiliki kemampuan untuk mengikat dua benda melalui ikatan permukaan. Semakin banyak jumlah perekat yang dicampurkan dengan arang menunjukkan nilai kalor yang semakin rendah [4].

Berdasarkan sumber dan komposisi kimianya, perekat dibagi menjadi 3 bagian yakni, perekat yang berasal dari tumbuhan seperti kanji, perekat yang berasal dari hewan seperti perekat kasein dan perekat sintetik yaitu perekat yang dibuat dari bahan sintetis [5].

\section{Metode Penelitian}

Alat dan Bahan. Adapun alat yang digunakan pada penelitian ini ialah timbangan, thermometer, alat pengaduk, ayakan, dan pirolisator.

Bahan yang digunakan pada penelitian ini ialah ampas tebu, tepung kanji, aquades dan bahan bakar kayu.

\section{Prosedur Kerja}

Preparasi Arang Ampas Tebu. Sebelum menjadi arang ampas tebu dikeringkan dibawah sinar matahari selama \pm 3 hari hingga kering. Ampas tebu dimasukkan ke dalam pirolisator pada suhu 200-350 $C$ selama 1 jam sampai menjadi arang ampas tebu. Kemudian arang ampas tebu yang dihasilkan digerus dan diayak dengan ukuran 60 mesh.

Pembuatan Larutan Kanji. Ditimbang 20 gram dan 40 gram tepung kanji lalu dilarutkan dengan aquadest, lalu diaduk sampai homogen. Larutan yang telah homogen kemudian dipanaskan hingga larutan kanji mengental.

Pembuatan Biobriket. Campurkan 40 gr serbuk arang tebu ukuran 60 mesh dengan larutan kanji sebanyak $20 \mathrm{gr}$, aduk sampai benar-benar rata. Masukkan adonan kedalam cetakan, lalu biobriket dikeluarkan dari cetakan. Kemudian biobriket dijemur selama 2 hari sampai kering. Lakukan tahapan sebelumnya dengan larutan kanji sebanyak $40 \mathrm{gr}$. Lalu amati perbandingan antara sampel perekat dengan komposisi $20 \mathrm{gr}$ dan $40 \mathrm{gr}$.

Pengujian Biobriket. Biobriket diukur kadar airnya menggunakan digital moisture meter. Uji kualitas 
pengukuran laju pembakaran dilakukan dengan cara membakar biobriket dan menghitung berapa lama biobriket terbakar habis. Uji kualitas pengukuran nilai kalor dilakukan dengan cara mengukur suhu awal pembakaran dan suhu akhir biobriket lalu menghitug nilai kalor.

\section{Hasil dan Pembahasan}

Ampas tebu merupakan salah satu contoh dari limbah industri dan limbah pertanian atau biasa dikenal sebagai biomassa. Pemanfaatan limbah ampas tebu dan ini dapat digunakan sebagai salah satu sumber bahan bakar alternatif, sehingga selain dapat mengurangi jumlah limbah yang diproduksi baik oleh pabrik maupun domestik, juga dapat menghemat penggunaan BBM. Hasil dari pemanfaatan limbah tersebut dapat dipasarkan sehingga memiliki nilai jual yang lebih dan dapat membantu mengurangi pemakaian BBM. Biomassa dapat digunakan langsung sebagai sumber energi panas, sebab biomassa telah mengandung energi yang dihasilkan dalam fotosintesis saat tumbuhan hidup. Penggunaan biomassa secara langsung sebagai bahan bakar kurang efisien, maka perlu diubah menjadi energi kimia terlebih dahulu, misalnya diubah menjadi biobriket dan bioarang. Sebab biobriket dan bioarang memiliki nilai bakar lebih tinggi dibandingkan biomassa [6]. Hasil penelitian yang dilakukan pada pengujian kadar air, nilai kalor, dan laju pembakaran dapat dilihat pada Tabel 1.

Kadar air. Berdasarkan hasil penelitian dan pengujian biobriket ampas tebu yang telah dilakukan, kadar air yang diperoleh pada komposisi perekat $20 \mathrm{~g}$ adalah $6,4 \%$, dan pada komposisi perekat $40 \mathrm{~g}$ adalah $9,8 \%$. Hasil penelitian menunjukkan briket ampas tebu pada komposisi perekat 40 gr mempunyai kadar air yang lebih tinggi dibandingkan yang lain. Dari hasil penelitian biobriket diperoleh penentuan kadar air merupakan banyaknya air yang terkandung dalam bahan yang dinyatakan dalam persen. Kadar air juga merupakan salah satu karakteristik yang sangat penting pada briket yang dihasilkan, dimana kadar air sangat berpengaruh pada kualitas briket. Ini disebabkan pemanasan dengan temperatur yang tidak tertentu pada briket karena menggunakan sinar matahari dalam proses pengeringannya. Gambar 1 menunjukkan hasil pengujian kadar air biobriket yang dihasilkan.

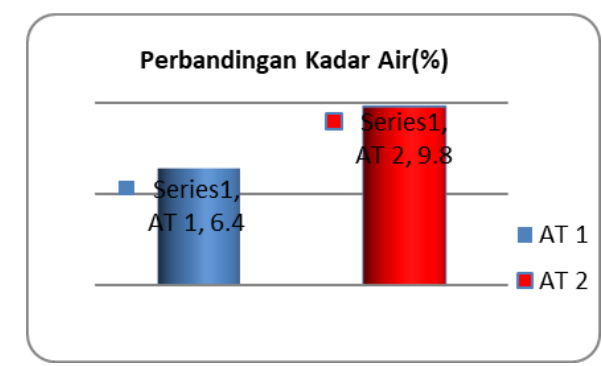

Gambar 1. Grafik perbandingan kadar air

Kadar air yang rendah dipengaruhi oleh lamanya pengeringan biobriket. Hal ini yang menyebabkan rendahnya kadar air pada briket. Kadar air sangat berperan pada kualitas briket yang dihasilkan, karena semakin rendah kadar air yang diperoleh maka kualitas briket yang dihasilkan akan semakin baik sehingga mempermudah proses pembakaran. Sedangkan kadar air yang tinggi akan menurunkan nilai kalor dan laju pembakaran karena panas yang diberikan digunakan terlebih dahulu untuk menguapkan air yang terdapat di dalam biobriket.

Hal ini dapat disimpulkan bahwa pengeringan mempengaruhi pada saat pemanasan perlakuan manapun. Kadar air yang diperoleh yang sudah memenuhi standar mutu briket arang kayu (SNI 016235-2000), yaitu 8\%. Berikut gambar pengukuran kadar air biobriket ampas tebu.

Laju pembakaran. Pengujian laju pembakaran adalah proses pengujian dengan cara membakar briket untuk mengetahui lama nyala suatu bahan bakar, kemudian menimbang massa briket yang terbakar. Lamanya waktu penyalaan dihitung menggunakan stopwatch dan massa briket ditimbang dengan timbangan digital [7]. Persamaan yang digunakan untuk mengetahui laju pembakaran adalah [7]:

Tabel 1. Uji kualitas biobriket

\begin{tabular}{ccccccc}
\hline KODE & T1 (C) & T2 (C) & m awal (gr) & $\mathbf{c}(\mathbf{c a l} / \mathbf{C})$ & $\mathbf{m}$ akhir $(\mathbf{g})$ & Waktu pembakaran (detik) \\
\hline AT 1 & 112.57 & 132.65 & 10 & 2575.6 & 5.63 & 188 \\
AT 2 & 109.38 & 127.84 & 13 & 2575.6 & 12 & 73 \\
\hline
\end{tabular}

Ket: $\mathrm{T} 1=$ suhu awal pembakaran $\left({ }^{\circ} \mathrm{C}\right)$

$\mathrm{T} 2=$ suhu akhir pembakaran $\left({ }^{\circ} \mathrm{C}\right)$

$\mathrm{C}=2575,6\left(\mathrm{Cal} /{ }^{\circ} \mathrm{C}\right)$ merupakan ketetapan setiap bahan yang dibakar untuk menaikkan $1{ }^{\circ} \mathrm{C}$ temperatur air 
Massa briket terbakar $(g)=$ massa awal-massa sisa (1)

Laju pembakaran $(g /$ det $)=\frac{\text { massa briket terbakar }(g)}{\text { waktu pembakaran }(\mathrm{det})}$

Berdasarkan pengujian laju pembakaran dilakukan untuk mengetahui efektifitas dari suatu bahan bakar. Hal ini untuk mengetahui sejauh mana kelayakan dari bahan baar yang diuji sehingga dalam aplikasinya nanti bisa digunakan. Laju pembakaran bioriket yang paling cepat terdapat pada komposisi perekat $20 \mathrm{~g}$ ampas tebu yaitu 0,023244681 (gr/det) sedangkan laju pembakaran bioriket yang paling lambat pada komposisi perekat $40 \mathrm{~g}$ ampas tebu yaitu 0,01369863 (gr/det). Laju pembakaran yang diperoleh dapat dilihat pada Gambar 2.

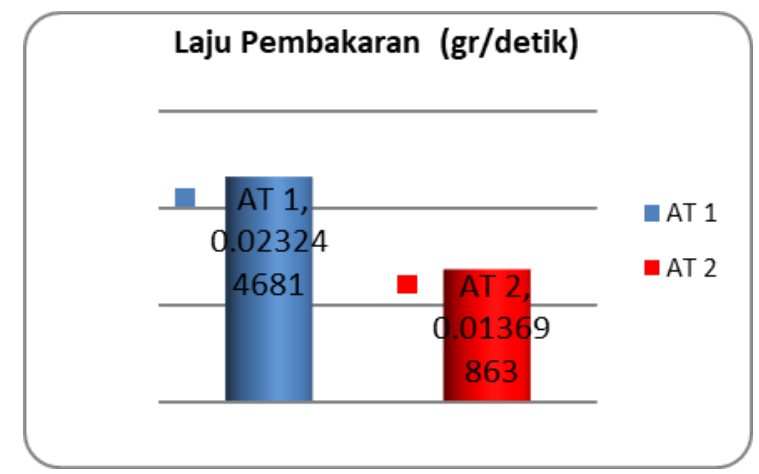

Gambar 2. Grafik laju pembakaran

Laju pembakaran semakin cepat maka besar pula nilai kalor yang dihasilkan. Laju pembakaran juga dipengaruhi oleh ukuran partikel, jumlah perekat, dan kuat tekan. Semakin besar kuat tekan dan ukuran partikel semakin kecil akan meningkatkan kerapatan massanya dan terjadi perpindahan panas secara konduksi sehingga panas akan mudah merambat dari partikel yang satu ke partikel yang lain dan tidak cepat habis atau waktu nyala semakin lama.

Nilai kalor. Berdasarkan SNI. 01-6235-2000, nilai kalor dikatakan baik apabila lebih dari 5000 kal/ gr. Perbandingan nilai kalor dari biobriket AT 1 dan AT 2, dimana biobriket AT 1 pada komposisi perekat $20 \mathrm{gr}$ memiliki nilai kalor $5171,8048 \mathrm{kal} /$ gr, dan AT 2 komposisi perekat 40 gr memiliki nilai kalor $3657,352 \mathrm{kal} / \mathrm{gr}$. Nilai kalor merupakan salah satu sifat penting untuk menentukan kualitas briket. Komposisi bahan baku sangat berpengaruh terhadap nilai kalor. Seperti pada penelitian sebelumnya yang dilakukan oleh Faizal, dkk [4]. Bahwa semakin rendah komposisi suatu bahan perekat maka nilai kalor yang dihasilkan semakin tinggi pula., sebaliknya semakin tinggi komposisi bahan perekat maka semakin rendah nilai kalor yang dihasilkan biobriket tersebut. Penambahan perekat juga menyebabkan nilai kalor biobriket semakin berkurang karena bahan perekat memiliki sifat termoplastik, dimana termoplastik artinya sulit terbakar dan membawa lebih banyak air sehingga panas yang dihasilkan terlebih dahulu digunakan menguapkan air dalam biobriket. Hasil pengujian nalai kalor ditunjukkan pada Gambar 3.

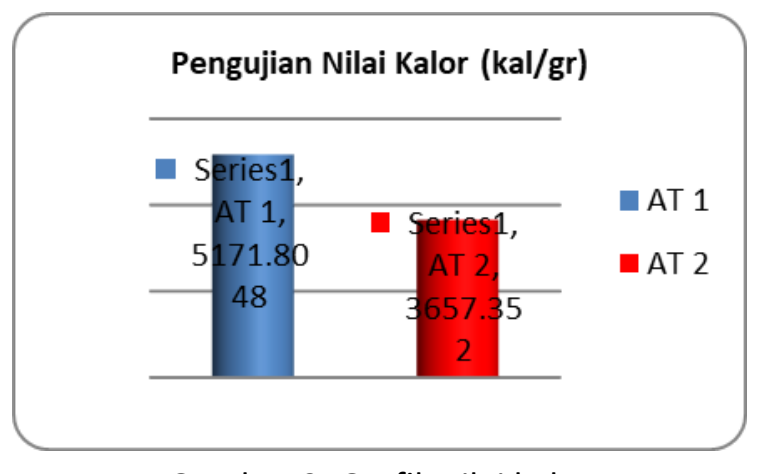

Gambar 3. Grafik nilai kalor

Dalam analisa nilai kalor untuk biobriket bioarang yang masih mengandung air yaitu Gross Energy (GE) atau nilai kalor bruto menggunakan persamaan 3 [7]:

Nilai kalor $(\mathrm{cal} / \mathrm{g})=\frac{\left(T_{2}-T_{1}\right)}{m} \times c$

Dimana :

$\mathrm{C}=2575,6\left(\mathrm{Cal} /{ }^{\circ} \mathrm{C}\right)$ merupakan ketetapan setiap bahan yang dibakar untuk menaikkan $1{ }^{\circ} \mathrm{C}$ temperatur air

$\mathrm{T} 1=$ Suhu awal selama pengujian $\left({ }^{\circ} \mathrm{C}\right)$

$\mathrm{T} 2$ = Suhu akhir selama pengujian $\left({ }^{\circ} \mathrm{C}\right)$

\section{KESIMPULAN}

Berdasarkan hasil penelitian pada briket ampas tebu yang telah dilakukan dapat disimpulkan bahwa Kualitas biobriket dipengaruhi beberapa faktor yaitu kadar air, nilai kalor dan laju pembakaran. Biobriket yang memiliki kualitas terbaik adalah pada AT 1 massa $10 \mathrm{gr}$ dengan komposisi perekat $20 \mathrm{gr}$ dengan nilai kadar air $6,4 \%$, nilai kalor $5171,8048 \mathrm{cal} / \mathrm{g}$, dan laju pembakaran 0,023244681 gr/detik. Sedangkan pada perbandingan kualitas briket pada AT 2 massa 13gr dengan komposisi perekat $40 \mathrm{gr}$ dengan kadar 
air 9,8\%, nilai kalor $3657,352 \mathrm{cal} / \mathrm{g}$, dan laju pembakaran 0,01369863 $\mathrm{gr} /$ detik. Oleh karena itu biobriket pada AT 1 dikategorikan sangat baik sehingga terbukti bahwa semakin rendah komposisi suatu bahan perekat maka kualitas briket yang dihasilkan semakin tinggi pula., sebaliknya semakin tinggi komposisi bahan perekat maka semakin rendah kualitas yang dihasilkan briket tersebut.

\section{References}

[1] Mwasilu, F. \& Jung, J. W. Potential for power generation from ocean wave renewable energy source: a comprehensive review on state-of-the-art technology and future prospects. IET Renew. Power Gener. 13. 363375. (2019). DOI: 10.1049/ietrpg. 2018.5456

[2] Kong, G. T. Peran Biomassa bagi Energi Terbarukan. (2013).

[3] Mariati, L. \& Yusbarina, Y. Pembuatan Biobriket Dari Gambut Dan Ampas Tebu Sebagai Sumber Belajar Materi IImu Kimia Dan Peranannya. Konfigurasi J. Pendidik. Kim. dan Terap. 1. 113-118. (2017). DOI: 10.24014/konfigurasi.v1i1.4064

[4] Faizal, M., Andynapratiwi, I. \& Putri, P. D. A. Pengaruh Komposisi Arang Dan Perekat Terhadap Kualitas Biobriket Dari Kayu Karet. J. Tek. Kim. 20. 36-44. (2014).

[5] Ningsih, E., Mirzayanti, Y. W., Himawan, H. S. \& Indriani, H. M. Pengaruh Jenis Perekat pada Briket dari Kulit Buah Bintaro terhadap Waktu Bakar. Pros. Semin. Nas. Tek. Kim. "Kejuangan” Pengemb. Teknol. Kim. untuk Pengolah. Sumber Daya Alam Indones. 1-8. (2016).

[6] Sundari, S., Papuangan, N. \& Jabid, A. PreDesign of Bio-Briquette Production Using Kenari Shell. IOP Conf. Ser. Earth Environ. Sci. 276. 1-7. (2019). DOI: 10.1088/1755$1315 / 276 / 1 / 012051$
[7] Almu, M. A., Syahrul, S. \& Padang, Y. A. Analisa Nilai Kalor dan Laju Pembakaran pada Briket Campuran Biji Nyamplung (Calophyllm Inophyllum) dan Abu Sekam Padi. Din. Tek. Mesin. 4. (2014). DOI: 10.29303/d.v4i2.61 